\title{
The Effect of Mathematics Instruction Integrated with Social Issues on Problem Posing Skill ${ }^{1}$
}

Buket Turhan Türkkan, Çukurova University, Turkey, bturhan@cu.edu.tr, ORCID: 0000-0003-2528-4022 Memet Karakuş, Çukurova University, Turkey, memkar@cu.edu.tr, ORCID: 0000-0002-6099-5420

\begin{abstract}
This study investigated the effect of mathematics instruction integrated with social issues on developing secondary school seventh grade students' problem posing skills. The study was carried out as an action research. Participants of the study were 17 seventh-grade students. In the study, a ten-week instruction was carried out. The quantitative data were collected with the Problem Posing Skill Test developed by the researchers. The qualitative data were collected by semi-structured interviews. Concerning data analysis, while the t-test was used for the dependent samples for quantitative data, inductive analysis was used for qualitative data. Results revealed significant differences between students' pre-test and post-test scores in favor of post-test, and qualitative findings also supported these results.
\end{abstract}

Keywords: Action research, mathematics education, problem posing skill, social issues

Received: 01.05.2020

Accepted: 05.08.2020

Published: 01.12.2020

\section{INTRODUCTION}

It is stated that the concept of social justice has an interdisciplinary qualification because it has many philosophical, sociological and historical features (Ball, 2001). Besides, social justice education is seen as a tool for students to learn and to use knowledge and skills for social sciences, science, reading and writing in mathematics for the purpose of creating a socially just society (Wade, 2007). Hence, it can be said that social justice education has interdisciplinary features and it is necessary to integrate various disciplines in this context. Mathematics is gaining importance as a tool for teaching social justice and equality issues. Regarding this, educators in search of social justice and equality see mathematics as a powerful tool to identify and overcome injustices in social life (Allen, 2003; Gonzalez, 2009; Gutstein, 2003; Gutstein, 2006; Koestler, 2010; Noyes, 2007; Skovsmose \& Nielsen, 1996; Spielman, 2008). It is believed that including social justice and equality issues in mathematics and other courses is vital for educational and social purposes as well.

When mathematics is considered as an integral part of a broader system raising educated citizens, it is necessary for students to understand their relations with mathematics to be able to understand local, national and global inequalities and provide solutions for them (Spielman, 2008). Besides, it presents a unique opportunity to combine research and practice, within the context of equality and social justice, mathematics education and other disciplines (Gutstein et al., 2005). In addition, the emphasis on social justice and equality in mathematics education is considered to be a large-scale practice because it involves different aspects of society and culture (Koestler, 2010). In conclusion, mathematics education plays an important role in the social and economic production of society, and it is increasingly necessary to include equality and justice within and outside the school (Hart, 2003). Based on these views, including social justice and equality issues in mathematics education through interdisciplinary connections is considered significant.

One of the ways of dealing with social issues such as social justice and equality is problem posing (Peterson, 2007a). In this context, it is considered that doing problem posing practices could be

${ }^{1}$ This study is a part of Dr. Buket TURHAN TÜRKKAN's doctoral dissertation.

A part of this study was presented at the Fifth International Congress on Curriculum and Instruction (2628 October 2017, Muğla, Turkey). 
regarded as a tool within mathematics instruction integrated with social issues. Thus, doing problem posing studies integrated with social issues arises as an alternative to the abstract exercises that some of students do not want to do and text based problems they do not want to solve (Peterson, 2007b). Accordingly, Gutstein (2003) also suggests that students should be involved in problem posing activities in order to understand these issues in education for social justice, equality and living conditions. It is thought that problem posing could be used in mathematics teaching with social aspects as learning to pose a problem found to be allowing students to process information and think in a critical and social context (Tanase \& Lucey, 2015). Gutstein (2003) suggests that in the context of social justice education, teachers should be able to address issues such as injustice, inequality and living conditions to help students and they could pose problems for understanding these issues and he also states that students will recognize these strengths and traditions that shape their worlds and identify their own problems as they mention these questions meaningful within their lives. Accordingly, problem posing is seen as an effective tool to make the discussions interesting and complex (Peterson, 2002). Based on these opinions, it is considered that taking as a basis problem posing skill for integrating mathematics with social issues can contribute to both students, society, world and mathematics for recognizing the social problems and solving these problems within mathematics. At first glance, it can be thought that social justice education should be at university level since the problems in the social context are very big and difficult but it is emphasized that this education should be started in primary school years (Wade, 2007). While Schniedewind and Davidson (2006) consider it is important to deal with social issues at middle school level, Peterson (2002) suggests that students at primary school level can understand some of the world's injustices and besides, he emphasizes the importance of social justice education through 12-18 age range in line with Erikson's Psychosocial Development Theory. Therefore, it is considered that the research on teaching mathematics integrated with social justice and equality issues at the middle school level are meaningful both in terms of middle school education's being appropriate for gaining attitudes and values, as well as filling the deficiency in the literature. It is thought that it would be more beneficial to carry out a study on the integration of social issues with mathematics at middle school level. In this study seen necessary for these reasons, answers were sought for the question "How does mathematics instruction integrated with social issues contribute to the seventh grade students' development of problem posing skill?"

\section{Problem Posing and Place of Problem Posing in Mathematics Education}

Problem posing is defined as the process of constructing a new problem by using a given situation, knowledge, question or problem (Cai et al., 2013; Kar \& Işılk, 2015; Siswono, 2010; Stickles, 2006). Similarly, Bonotto (2010) regards problem posing as a process in which students construct personal interpretations for concrete situations and formulate them as meaningful mathematical problems. Katrancı and Şengül (2015) also see problem posing as a process based on mathematical experience and interpretations created by concrete situations' being transformed into meaningful mathematical problems. Moreover, problem posing is defined as producing new questions in a way that includes research, investigation and exploration (Çıldır \& Sezen, 2011; Yıldız \& Özdemir, 2014). Hence, it can be said that problem posing is the process of creating new problems from given situations or problems by researching and analyzing and using individual interpretations.

Problem posing is recognized as an important mental activity in scientific researches (Cai, Hwang, Jiang \& Silber, 2015). Besides, problem posing is also considered as a creative activity for mathematics education (Arıkan \& Ünal, 2015). Similarly, it is stated posing a problem involves producing something new or revealing a new thing from a set of data, and thus, somehow, incorporates creativity (Singer \& Voica, 2015). Furthermore, problem posing is considered as a necessary skill for problem solving in everyday life (Kojima, Miwa \& Matsui, 2015). Problem posing is seen as a growing and stepping stone for development of curiosity as well (Osana \& Pelczer, 2015). Finally, problem posing is defined as one of the keys to mathematical discovery (Cai \& Hwang, 2002) and is seen a way of analytical thinking (Katrancı \& Şengül, 2015). With this respect, it can be said that problem posing is a beneficial and important activity especially in 
cognitive context. Recent studies on problem posing, dating back to the 1980s (Osana \& Pelczer, 2015), have been drawing attention of mathematics education researchers in the last decade but it is stated that there are various deficiencies regarding problem posing (Cai, Hwang, Jiang \& Silber, 2015; Harpen \& Sriraman, 2013). Furthermore, although problem posing is included in mathematics curriculum, it is stated that problem posing is not applied too much in teaching processes (Akkan, Çakıroğlu \& Güven, 2009; Bonotto, 2010; Ellerton, 2013; Klaassen \& Doorman, 2015; Kojima, Miwa \& Matsui, 2015; Tertemiz \& Sulak, 2013; Van Harpen \& Presmeg, 2013), it is mentioned that more attention should be paid to problem posing (English \& Watson, 2015; Klaassen \& Doorman, 2015) and more detailed studies about problem posing are needed (Cai et al., 2013; Cai et al., 2015). In this respect, it is revealed that revising the place and importance of problem posing within curricula, giving them more space in mathematics instruction practices, being given more attention by the researchers and doing more comprehensive and detailed studies are required for eliminating the deficiencies of giving place to problem posing studies in mathematics teaching.

Despite negative situations mentioned above for problem posing, there are positive initiatives and practices in this area as well. Problem posing is seen as an important skill in mathematics instruction as much as problem solving (Kojima, Miwa \& Matsui, 2015) and considered to be at the center of mathematical thinking with problem solving (Arıkan \& Ünal, 2015). Problem posing is seen as a classroom activity as problem solving and interest in problem posing in mathematics instruction is increasing (Cai, et al., 2013). In addition, problem posing has received increasing interest within mathematics education research in recent years (Ișık \& Kar, 2012). Moreover, it is indicated that there is also problem posing among the subjects that the educators are addressing carefully (Çıldır \& Sezen, 2011; Osana \& Pelczer, 2015). The interest in problem posing is also seen in the curricula and in the documents guiding the curricula (Kar \& Işı 1 , 2015). In addition, within the past few years, researchers have realized that problem posing is a vital component as much as problem solving (Arıkan \& Ünal, 2013a). It is stated that problem posing studies are required (Şengül \& Katrancl, 2014) considering that problem solving and problem posing skills are undoubtedly among the most effective methods within the objectives of mathematics education in the curriculum (Çıldır \& Sezen, 2011). Thus, nowadays, it can be said that there are positive views on mathematical problem posing.

Problem posing is considered as an important mathematical activity; it is stated that problem posing has many contributions for students, teachers and researchers and an important role in mathematics instruction as well (Toluk-Uçar, 2009; Işık, Çiltaş \& Kar, 2012; Kılıç, 2012; Kılıç, 2013a; Chen, Van Dooren \& Verschaffel, 2015; Milinković, 2015; Rosli, Capraro, Goldsby, Gonzales, Onwuegbuzie \& Capraro, 2015; Van Harpen \& Presmeg, 2013). When theoretical and empirical studies are analyzed within the literature, it is possible to determine the mentioned positive effects of conducting problem posing studies within mathematics instruction. It is indicated that, including problem posing studies in mathematics instruction contributes understanding mathematical problem situations and establishing a solid basis for generating new problems (English, 1997), besides helping students to understand the problem situations, it also contributes to the development of more advanced problem solving strategies (Cai et al., 2013; Cai et al., 2015). Furthermore, it is mentioned that problem posing studies provide students with not only solving problems in textbooks, but also analyzing the explanations in the problem and better understanding the information they will need to solve the problem (Solórzano, 2015). In addition, it has been pointed out that doing problem posing practices not only improves students' problem solving skills but also develops habits of thinking about enriching and reinforcing basic mathematical concepts (Kwek, 2015) and helps students develop positive attitudes towards mathematics (Cai \& Hwang, 2003). It is also stated that, problem posing instruction improves creativity, critical thinking and inquiry skills (Silver, 1997; Arıkan \& Ünal, 2014). Considering these positive effects of problem posing studies, it is thought that more attention should be given to problem posing in mathematics curricula and practices for teaching mathematics.

\section{METHODS}




\section{Research Model}

This study was conducted with the action research model. Action research is an approach the practitioner is on his/her own or with a researcher in the research process, and it is aimed to understand and solve the problems of the application process or a present problem before the application (Yıldırım \& Şimşek, 2008). Action research contributes to creating a better, more free and fairer society through cooperative problem analysis and problem solving within a context (Greenwood \& Levin, 2007). In action research, it is tried to make the social world including many problems understandable and to improve the social quality of life (McKernan, 1996). Besides, action research is a part of practice-based research (McNiff, 2013). In this context, it is stated that those who advocate action research are usually related to educational research about social justice (Freebody, 2004). It is also stated that when critical mathematics education is associated with research, it is usually shaped by action research (Skovsmose \& Nielsen, 1996). Since the study included social justice education and critical mathematics education, it was thought that the design should be action research accordingly.

\section{Participants}

Among purposeful sampling methods, criteria sampling was used to determine participants in this study. In purposeful sampling, researchers select individuals or groups that will reveal information rich situations for the research question (Devers \& Frankel, 2000). The researcher actively chooses the most efficient sample in order to answer the research question (Marshall, 1996). Criteria sampling is defined as the sampling method in which the sampling units are selected within the framework of predetermined criteria according to the researcher's or a previously prepared criteria list (Baş \& Akturan, 2008). The following criteria were taken into consideration in the determination of participants: attending seventh-grade mathematics lessons in a public school located in a region with middle socioeconomical level there being problems about the problem posing skill. The study was conducted at seventh grade level because in this age group, individuals' personalities are determined and attitudes and values are effectively gained. Accordingly, during second semester in 2014-2015 education year, research participants were 17 seventh-grade students (8 girls and 9 boys) in public school located in a region with middle socioeconomical level, Adana Province, Turkey. Students were taking a mathematics practices course from the observer teacher. To determine participants' problem posing skill, the Problem Posing Skill Test (PPST) was administered and interviews were also conducted with participants before the action research process. Table 1 presents pre-test scores' statistics, and findings from pre-instruction interviews are presented under 'Findings' for comparison with post-instruction interviews.

Table 1. Statistics on pre-test scores for the problem posing ability

\begin{tabular}{ccccccccc}
\hline $\begin{array}{c}\text { Number of } \\
\text { Participants }\end{array}$ & Mean & $\begin{array}{c}\text { Standard } \\
\text { Deviation }\end{array}$ & Mode & Median & Min. & Max. & Skewness & Kurtosis \\
\hline 17 & 54.59 & 20.46 & 35 & 55 & 19 & 89 & -.097 & -.981 \\
\hline
\end{tabular}

As on Table 1, mean of participants' PPST pre-test scores was 54.59 (120-point scale), so their awareness level was low. Also, preliminary interviews revealed that there were problems about problem posing skill. Therefore, it was thought that the problem posing skills of these students should be developed and it was decided that the action research should be carried out with these students.

\section{Researchers' Role}

In action research, researchers and practitioners observe and make inquiries about themselves preferring conducting research on themselves (McNiff, 2013). Altrichter, Feldman, Posch, and Somekh (2008) have indicated that action research can be conducted by teachers alone, but practices without stakeholders' participation will lack sustainability. Similarly, McNiff and 
Whitehead (2010) emphasize the importance of working collaboratively in action research. Yıldırım and Şimşek (2008) stated that in the action research, the practitioner can be a researcher at the same time, and the researchers and practitioners can carry out action research together as well. The researcher has studies and practices related to teaching social justice and equality and problem posing and she also has 3,5 years of teaching experience at middle school level. It is thought that it would be more appropriate for the researcher to carry out the instruction instead of the formal teacher as she does not have enough knowledge about social justice education and problem posing instruction. In line with this, the formal teacher has acted as an external observer and presented her views about the instruction process. So, the researcher, collected the data before, during and after the instruction; analyzed the data, prepared the action plans and carried out the instruction as a "researcher teacher".

\section{Data Collection and Tools}

Action research is a way to study within the field to benefit from multiple research techniques aimed at increasing change and generating data for scientific information production (Greenwood \& Levin, 2007). While qualitative research approaches are more used in action research, quantitative data collection methods could also be included (Yıldırım \& Şimşek, 2008). Moreover, it is also asserted that it is not correct to conduct action research only with a qualitative approach, and action researchers are required to be competent in all research approaches in the field of social sciences (Greenwood \& Levin, 2007). Hence, it can be said that both qualitative and quantitative data can be used in the process of action research. In this context, it could be stated that quantitative data can be used to determine the current situation and observe the changes through the process while qualitative data would be used to elucidate the causes of the changes in the process of action research. For this reason, both qualitative and quantitative data collection techniques were used to determine the current situation, examine the instructional process and determine the changes within the process. Qualitative data were collected through semistructured interview form while quantitative data were collected by the Problem Posing Skill Test developed by the researchers. In particular, information on these data collection tools is presented below.

\section{Problem posing skill test}

In order to determine students' problem posing skill, the researcher used a skill test consisting of open-ended questions and a rubric to evaluate the test. In The Middle School Mathematics Curriculum, the seventh grade level includes the following learning areas and subjects (Ministry of National Education, Turkey, 2013b): numbers and operations learning area (whole numbers, rational numbers, ratio and proportion, percentages), algebra learning area (equality and equation, linear equations), data processing learning area (producing research questions, data collection, editing), evaluation and interpretation learning area (central tendency and diffusion measures). In Middle School Mathematics Practices Course Curriculum the seventh grade level includes attainments about the following subjects (Ministry of National Education, Turkey, 2013a): whole numbers, fractions, decimal numbers, percentages, rational and real numbers, ratio and proportion, linear relations and patterns, central tendency and diffusion measures and tables and graphs. Accordingly, it was decided to integrate these subjects included in the seventh grade, mathematics and mathematics practices curricula into the Problem Posing Skill Test (PPST). An example question is given below:

\section{Question 5: Ali got 72, 93 and 54 scores from mathematics exams. What is the mean of Ali's exam scores? \\ Pose a new problem related to measures of central tendency and diffusion changing the information given in the problem above. \\ Note: You can make any changes within the problem. You can change numbers, operations or used names/objects.}


Four experts from the Department of Curriculum and Instruction and two experts from the Department of Mathematics Education reviewed the PPST and its rubric so that a pilot form was prepared by making changes in line with their opinions. During the 2014-2015 education year's first semester, the pilot form was applied to 100 seventh-grade students in two similar public schools. Afterwards, the PPST's Spearman-Brown reliability coefficient was calculated at 0.79 . Both the researcher and an experienced mathematics teacher scored the data on the trial form. The Pearson coefficient for inter-scorer reliability on total scores was 0.99 . Pearson correlation coefficients for the rubric's subscales were: 0.99 in the difficulty dimension, 0.99 in the using the intendeds dimension, 0.95 in the solubility dimension, 0.99 in the originality dimension and 0.99 in the language and expression dimension. These studies showed that the PPST is a valid and reliable instrument for determining students' level of problem posing skills. There are eight questions in the PPST. The minimum score that can be taken from the PPST is 40 and the maximum score is 120 . The PPST was implemented twice, before and after the instruction.

\section{Semi-structured interview form for determining students' views on problem posing skill}

Researchers prepared an interview form to determine the students' pre-instruction status and to examine instruction's effects. Seven curriculum and instruction experts determined the interview form's validity, and changes were made in line with their opinions. The interview form was administered to all of the participants both before and after the instruction. Interviews were made by 17 participants both before and after the instruction.

\section{Data Analysis and Validity-Reliability Studies}

A rubric of five dimensions and three achievement levels was used in analysis of PPST data, including level of difficulty, using the intendeds, solubility, originality and language and expression. Scores were 1 at preliminary level, 2 at successful level, and 3 at exemplary level. Statistical analyses were performed on total scores. Since pre-test, post-test and difference scores were normally distributed, the t-test was performed for dependent samples from parametric tests.

Through analysis of interview data, the inductive approach within content analysis was used. Content analysis is used to reveal the main contexts and meanings in the qualitative data of a certain size and the main purpose of this process is to come up with patterns and themes that can explain the collected data (Patton, 2002). In content analysis, it is aimed to increase the inferential quality of the results by associating the frame obtained from the content and the data with the categories (Downe-Wamboldt, 1992). Inductive analysis involves the determination of patterns, themes and categories and findings are revealed in the direction of researcher's interaction with data; in qualitative data analysis, inductive analysis is used when codes, themes, and patterns are generated (Patton, 2002). Content analysis is basically composed of four stages and these are (Ylldırım \& Şimşek, 2008): coding the data, determining the themes, organizing the codes and themes, defining and interpreting the findings. First, voice recordings were transcribed, transferred to the NVIV010 programme and analysed. Through NVIV010 programme, coding primarily took the direction of the inductive approach, and then themes were created by combining relevant codes. After codes and themes were determined, models showing the holistic relation of them were created.

In the research process, verification strategies for establishing both reliability and validity are activities like providing methodological suitability, providing sample suitability, creating a dynamic relationship between data collection and data analysis, thinking theoretical and developing theory (Morse, Barrett, Mayan, Olson \& Spiers, 2002). In qualitative research, there are many perspectives on definition of validity and reliability, conditions and principles for preventing validity and reliability (Creswell, 2013). In validity and reliability studies regarding the qualitative data from interviews, the following techniques were applied: triangulation, peer examination and longtime interaction. Within triangulation process, both qualitative and quantitative data were analyzed in the research by using different research methods, thus trying to provide method diversity. Moreover, diversification of data collection tools was tried to be achieved by using interviews and skill test. As for peer examination, the second author of the 
research examined the analyzes of the first author. In this context, the second author reviewed the codes and the themes that the first author generated during the data analysis process and reported his opinions and suggestions and so necessary corrections were done. Besides, from the planning of the research till its completion, opinions were obtained from a validity committee consisting of three experts. Six meetings were held with the validity committee during the research process. Regarding long term interaction, sufficient time was provided for interaction with participants before the instruction and it continued throughout the whole semester.

Evaluations made using rubrics usually depend on the judgment of the scorer (Johnson, Penny \& Gordon, 2000) and since scoring should not change from one scorer to another, it will be useful to conduct reliability studies (Kutlu, Doğan \& Karakaya, 2010). Therefore, for the reliability of quantitative data obtained from rubric, it was thought that two more experts' scoring besides the researchers would contribute to the reliability. Kendall's Coefficient of Concordance was calculated to determine scorer reliability: The three evaluators had statistically significant agreement on pre-test $(\mathrm{W}=.85, \mathrm{p}<.05)$ and post-test evaluations $(\mathrm{W}=.82, \mathrm{p}<.05)$ so that the three evaluators were provided with confidence in both pre- and post-test scores. By comparing the scores of the three evaluators, it was determined that both the pretest and posttest scores were reliable.

\section{Action Research Process}

Action research is generally made up of a series of helix processes involving self-reflection cycles: planning a change; acting for a change and result process and doing observation; doing reflections on these processes and results; re-planning (Kemmis \& Wilkinson, 1998). In this study, action plans for each cycle were prepared, implemented, reflected, evaluated, and the results reached at the end of the evaluation process were reflected within the next action plan. The implementations for the action research process are summarized below. The issues included in the implementation are shown in Figure 1.

The lesson plan of the first week was prepared for the basic concepts of equality and social justice within the introduction to social issues. This lesson lasted for two hours and it was aimed to gain five goals during the lesson. In this lesson, basic concepts such as justice, social justice, equality, discrimination, sub-dimensions of equality and social justice were included. In addition to making students learn these basic concepts and sub-dimensions, it was also aimed to make them explain the relation of mathematics with social issues and recognize the importance of mathematics in revealing social problems. This lesson was planned as explained above because of its being the first lesson and students' lack of knowledge about these basic concepts and so presentation, lecture, discussion and idea discussion were mainly used methods and techniques throughout teaching process. Evaluation was completed through the evaluation sheet and selfevaluation form for these concepts and sub-dimensions. 

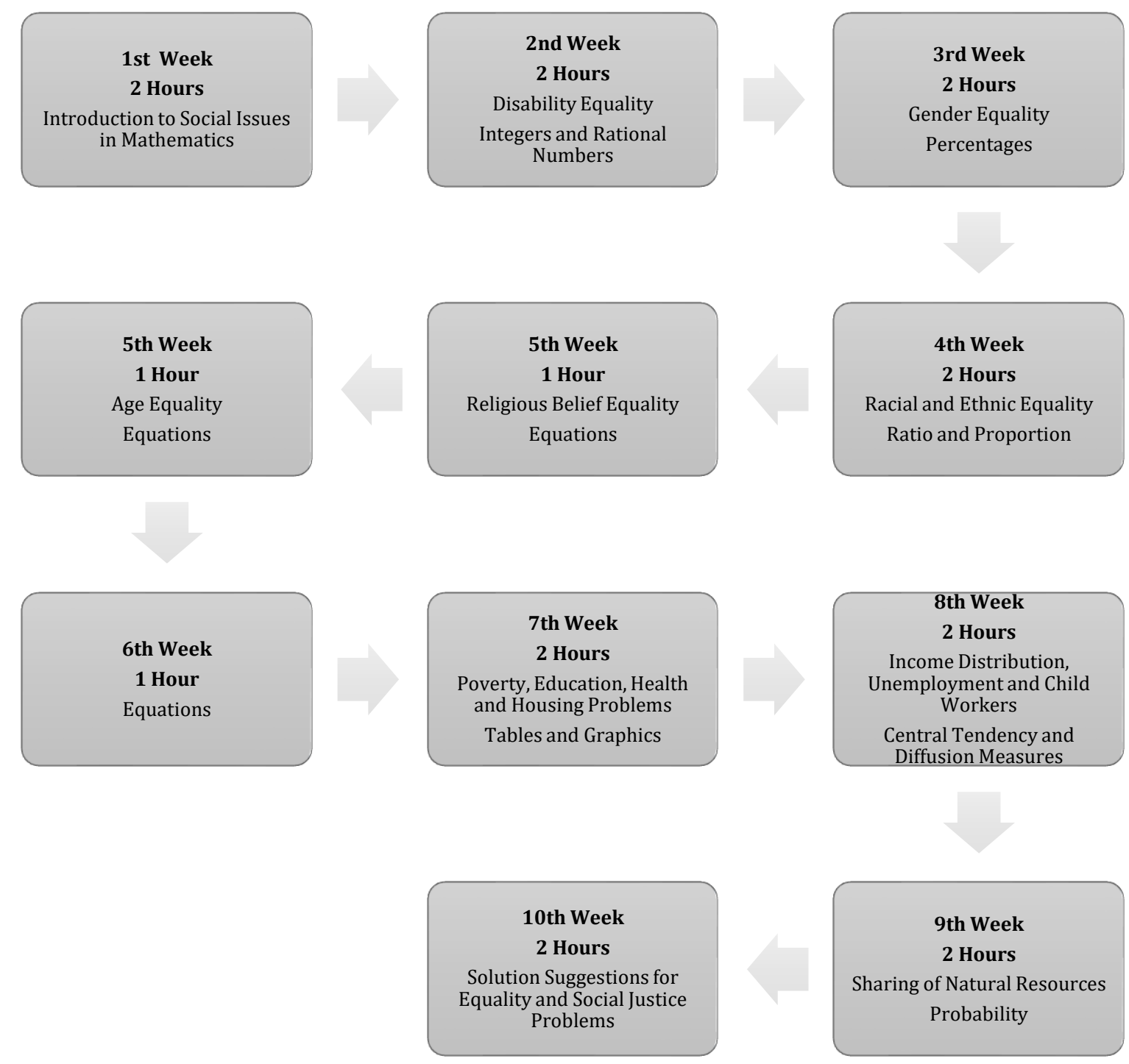

FIGURE 1. Issues included in the implementation

In the second week's lessons, regarding social justice and equality education disability equality and through mathematics instruction the integers and rational numbers were taught. This lesson lasted for two hours, two attainments from mathematics practices curriculum and five attainments about social justice and equality values had been included. In this lesson plan, it was aimed to help students explain the problems experienced by disabled people, interpret the numerical data related to the equality of disabled people, solve and pose problems related to the equality of disabled people, and understand the importance of mathematics in realizing the situations related to disability. As this course was integrated with mathematics practices, more problem solving and problem posing activities were introduced and studies were carried out to discuss the relation between disability equality and mathematics. At the end of the lesson, the evaluation was completed with an evaluation sheet which includes a mathematical problem related to the disability, and discusses this problem and a self-evaluation form.

In the third week concerning social justice and equality education, the subject of gender equality and within mathematics 'percentages' were included. This lesson lasted two hours and aimed to gain a total of six attainments, one for mathematics course and five for social justice and equality. In this lesson plan, the purpose was to make students understand the importance of gender equality through mathematical problems, realize that women and men are equal in life even though they have different roles, interpret numerical data on gender equality, solve and pose 
problems about both percentages and gender equality. Through this lesson, activities were conducted on problem solving and problem posing with direct instruction and studies were done on discussing the relation between gender equality and mathematics. An evaluation form about a mathematical problem integrated with gender inequality was used and then a discussion was conducted on this problem at the end of the lesson. A self-evaluation form was used as well. Besides homework about posing a semi-structured problem related to gender equality was given. In the fourth week, within the scope of social justice and equality education, racial and ethnic equality, and regarding mathematics course, the ratio-proportion were included in the instruction. The lesson lasted two hours and two attainments from mathematics practices curriculum and five attainments about social justice and equality values were covered. In this lesson plan, the aim was to let students determine problems about racial and ethnic equality, recognize that individuals of different race and ethnic origin are equal in life, even if they differ in various aspects, comprehend the importance of equality in terms of race and ethnic origin through math problems, solve and pose mathematical problems for equality in terms of race and ethnic origin. During this lesson, mathematical problem-posing activities were included and practices were conducted to discuss the relation between racial and ethnic equality and mathematics. For the evaluation of the lesson, self-evaluation form was used.

In the fifth week, related to social justice and equality education, religious belief equality and age equality, and within mathematics course, the equality and equations were included. This lesson lasted two hours and one attainment from mathematics practices curriculum and six attainments about social justice and equality values were involved in these lesson plans. In the first lesson plan, the aim was students' recognizing the problems about the religious belief equality in society via mathematics, solving mathematical problems related to religious belief equality and defending that all people are equal even if their beliefs are different. In the second lesson plan, the purpose was to make students recognize the problems about age equality in society by mathematics, solve mathematical problems related to age equality and give examples of age discrimination against individuals. Within this course, mathematical problem solving activities were included and practices were conducted to discuss the relation between religious belief and age equality and mathematics. For evaluation within the lesson, self-evaluation form was used. Towards the end of lesson, students were given a homework sheet to create problems in order to develop their problem posing skills.

In the sixth week, no activity was conducted regarding social justice and equality education. Only problem posing practices about equations were included. Through this lesson, a group activity was carried out to ensure cooperative learning. Within this activity, a worksheet was used including two questions, one of which was carried out with group, and the other one was conducted individually. During this lesson, problem posing activities were not integrated with social issues. As for evaluation, the problems that students individually posed were scored and self-evaluation form was used.

In the seventh week, within the scope of social justice and equality education, poverty, education, health and housing problems, and in the context of mathematics course, tables and graphics were included. The lesson lasted two hours and one attainment from mathematics practices curriculum and ten attainments about social justice and equality values were involved within the lesson plans. In the first lesson plan, the aim was to help students recognize the poverty problems via mathematics, interpret the numerical data about poverty in the context of social justice, see examples showing the injustice situations of poor people, solve and pose mathematical problems about poverty. In the second lesson plan, the purpose was students' recognizing the social problems about education, health, housing and nutrition via mathematics, discussing the reasons of these problems and the effects on the individuals, defending that all individuals have equal rights in education, health, housing and nutrition, and posing mathematical problems about these issues. Self-evaluation form was used for the evaluation. At the end, two performance tasks were given consisting of posing mathematical problems and proposing solutions to the problems about equality and social justice.

In the eighth week, concerning social justice and equality education, income distribution, unemployment and child workers, and regarding mathematics course, central tendency and 
diffusion measures were included. This lesson lasted two hours and two attainments from mathematics practices curriculum and six attainments about social justice and equality values were covered within this lesson. In the first lesson plan, it was aimed for students to interpret the income earned by individuals performing the same labor force in Turkey and other countries via central tendency and diffusion measures within social justice, to solve the mathematical problems about income distribution, to advocate that individuals who work in similar jobs should receive equal pay. In the second lesson plan, the aim was to make students interpret the numerical data of the situations about unemployment and child workers via central tendency and diffusion measures, solve the problems about unemployment and child workers and discuss the social problems about unemployment and child workers within the context of social justice. Within the evaluation of the lesson, self-evaluation form was used.

In the ninth week, within social justice and equality education, sharing natural resources, and for mathematics course, probability were included. This lesson lasted two hours and two attainments from mathematics practices curriculum and five attainments about social justice and equality values were covered up. In this lesson plan, it was targeted to help students recognize the problems of sharing the natural resources in the world and in Turkey via mathematical problems, discuss the situations that may arise as a result of the unjust sharing of natural resources, defend that natural resources should be distributed fairly to all mankind, solve mathematical problems about sharing natural resources and probability and pose problems about probability. Through the evaluation self-evaluation form was used.

In the tenth week, regarding social justice and equality education, solution suggestions for equality and social justice problems were included. This lesson lasted two hours and five attainments about social justice and equality values had been covered. In this lesson plan, the purpose was students' believing that social justice and equality should be ensured to solve social problems, presenting solution suggestions for sub-dimensions of equality and social justice, defending that everyone should be sensitive to the solution of social problems and being willing to take part in the solution of social problems about social justice and equality issues. For evaluation, self-evaluation form was used.

\section{Ethical Issues}

Within the ethical dimension of the study, some precautions were taken. Firstly, permission was received from Adana Provincial Directorate of National Education. After obtaining the necessary permissions and determining the class for instruction, the parents of the students participating in the study were informed about the practices to be carried out and the data to be collected and their written permissions were obtained. However, the students in the classroom that the instruction was carried out were given the necessary information regarding the purpose of the study. In addition, the students were asked whether they were volunteer for the research or not, and after the students were determined to participate voluntarily, the instruction was started. Before the interviews were carried out, the participants were asked whether they agreed to participate in the interviews voluntarily, whether they allowed to use of a voice recorder or not, and they were also informed that they could put an end to the interviews whenever they want throughout the interview. Finally, writing the research report, the school and the names of the students were not included within any part of the study and codes were assigned to the participating students instead of their original names.

\section{FINDINGS}

The PPST was used to determine how integrating mathematics instruction with social issues contributed to seventh-grade students' development of problem posing skill. Table 2 displays their mean pre- and post-test scores to show any significant difference and to indicate the instruction's effectiveness. 
Table 2. Averages of pre- and post-test scores for participants' problem posing ability

\begin{tabular}{ccccccc}
\hline Test & $\begin{array}{c}\text { Number of } \\
\text { Participants } \\
\text { (N) }\end{array}$ & Mean (X) & $\begin{array}{c}\text { Standard } \\
\text { Deviation } \\
\text { (Sd) }\end{array}$ & t-score & $\begin{array}{c}\text { Degree of } \\
\text { Freedom } \\
\text { (Df) }\end{array}$ & $\begin{array}{c}\text { Significance } \\
\text { Level (p) }\end{array}$ \\
\hline Pre-test & 17 & 54.59 & 20.46 & & & \\
\hline Post-test & 17 & 70.82 & 16.08 & -3.187 & 16 & $.006^{*}$ \\
\hline${ }^{*} \mathrm{p}<.01$ & & & & & &
\end{tabular}

Table 2 indicates significant difference between pre- and post-test scores. Thus, according to quantitative data, students' level of problem posing ability increased significantly after instruction. Qualitative findings from pre- and post-interviews were compared after content analysis, as explained below.

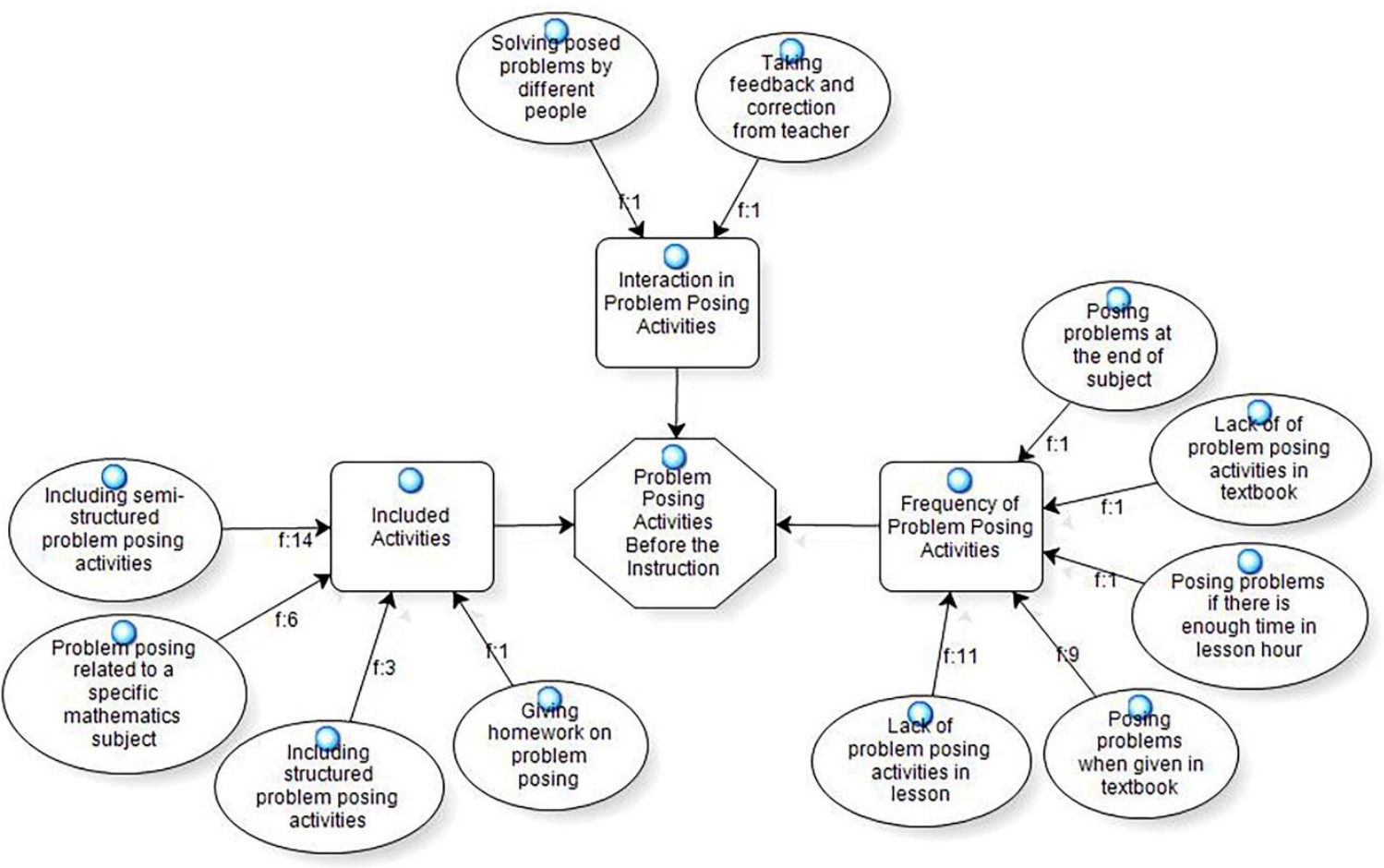

FIGURE 2. Students' views on problem posing activities included in the lessons before the instruction

As it is seen from Figure 2, students' views on problem posing activities were collected under three themes before the instruction: Included activities (f:24), frequency of problem posing (f:23) and interaction in problem posing activities (f:2). Students mostly expressed their views on problem posing activities in relation to these codes: Including semi-structured problem posing activities (f:14), lack of problem posing activities (f:11), posing problems when given in the textbook (f:9), problem posing related to a specific mathematics subject (f:6). Regarding this theme, S17 addressed the problem posing frequency as: "We do occasionally problem posing activities in the normal course but we do not encounter much." $\mathrm{S} 1$ stated about the posing problems when given in the textbook code, "No, not many. If included in textbooks or in some subjects, teacher gives us two or three examples, we are posing problems in another way by ourselves." Based on the students' views, it was determined that problem posing activities were given little space in mathematics and mathematics practices courses. 


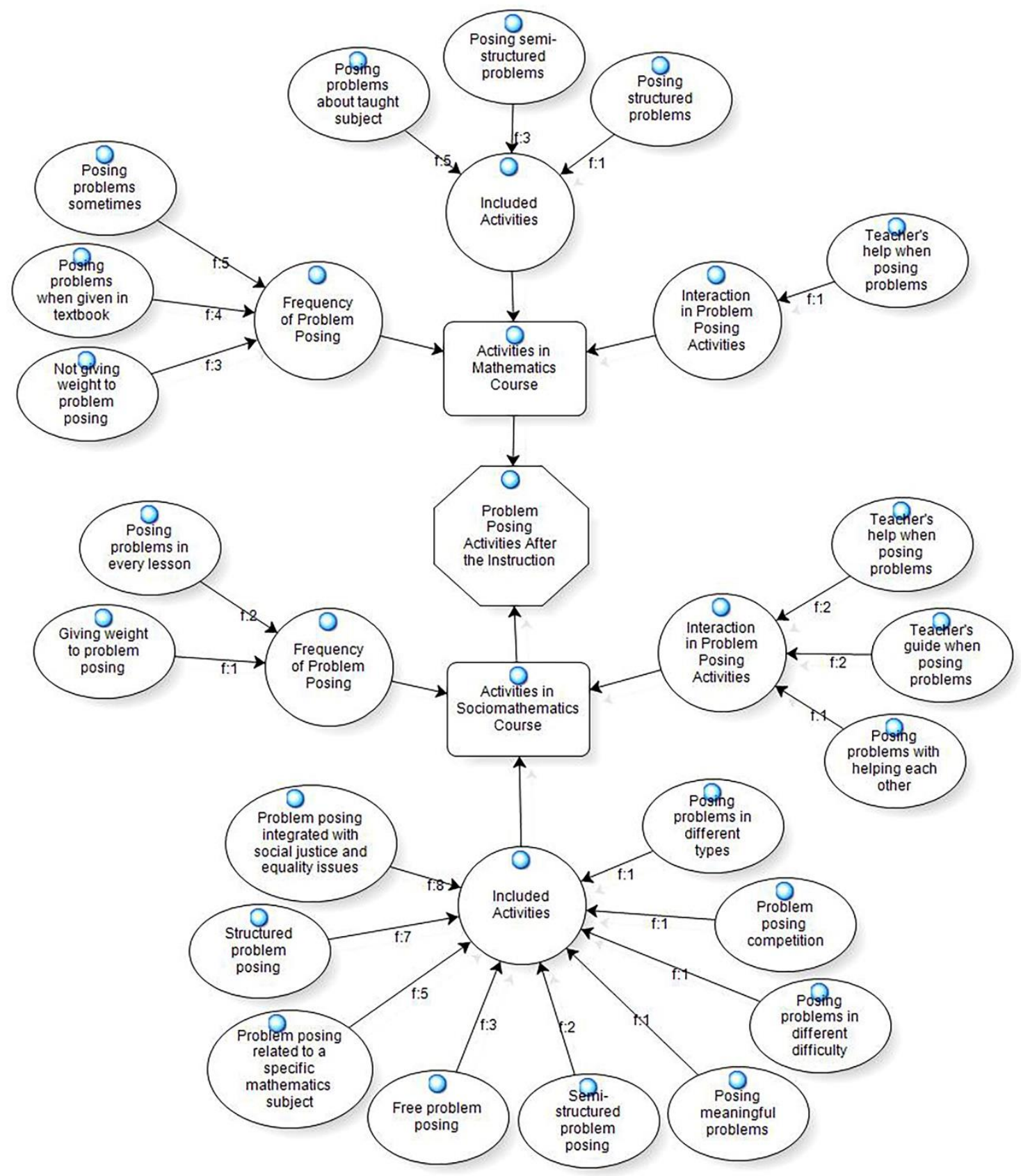

FIGURE 3. Students' views on the problem posing activities included in the lessons after the instruction

As it is on Figure 3, students' views on problem posing activities were collected under two dimensions after the instruction as in sociomathematics course and mathematics course (Through the instruction process integrated mathematics instruction with social issues called as sociomathematics course by the students). The themes for both of these dimensions were created separately. Views on problem posing activities in mathematics course were gathered under three themes: Frequency of problem posing (f:12), included activities (f:9) and interaction in problem posing activities (f:1). With regard to frequency of problem posing, students stated that they sometimes pose problems in mathematics course (f:5). Besides, there were views about posing problems when given in the textbook (f:4) and not giving weight to problem posing (f:3). Within this theme, S1 said "Generally too little... Teacher does that sometimes, once a year, one time." while S3 stated "That is to say, we don't pose much." With respect to problem posing activities in 
mathematics course theme, students mostly expressed their views under posing problems about taught subject (f:5). However, students also put forward their views about posing semistructured problems (f:3) and posing structured problems (f:1). Concerning this theme S17 expressed his views as "We usually pose for a subject, for example a subject is given, such as a ferris wheeel's diameter, teacher says us to pose a problem like this. Our teacher doesn't say anything to pose problem the way you want. There is the subject in the textbook, we pose about it." Within the interaction through problem posing theme in mathematics course S10 stated regarding teacher's help "Our teacher doesn't make it like you but she helps us too."

For the second sub-dimension, students' views on problem posing activities in sociomathematics course were gathered under three themes: Problem posing activities (f:29), interaction through problem posing (f:5) and frequency of problem posing (f:3). Related to problem posing activities in sociomathematics course, students' views were most frequently about problem posing integrated with social justice and equality issues (f:8) and structured problem posing activities (f:7). Besides, students' views were also about problem posing related to a specific subject (f:5), free problem posing (f:5), semi-structured problem posing (f:3), posing meaningful problems (f:1), posing problems in different difficulty (f:1), problem posing competition (f:1) and posing problems in different types ( $\mathrm{f}: 1$ ). For this theme S5 said comparing sociomathematics and mathematics courses, "What is given in the course, for example, if the subject is probability, you should try to pose a problem by using the data given about the subject of probability. We do this way. In your course you say 'pose a problem' or you give a text then you say 'you can change the text or the numbers and then you can pose a problem'. I think this is better in sociomathematics course, in almost every lesson, I mustn't say almost, in your every course we were posing problems. My problem posing skill is improved too but in mathematics course sometimes we don't pose problems." Within the context of interaction in problem posing theme, there were views about teacher's help when posing problems (f:2), teacher's guide when posing problems (f:2) and posing problems with helping each other (f:1). In this theme S10 said: "We do with helping each other but even if we don't help each other our teacher helps us, she says us how to do, how to pose." In frequency of problem posing theme, there were codes about posing problems every lesson (f:2) and giving weight to problem posing (f:1).

When students' views about problem posing activities included in the course were compared before and after the instruction, students expressed their views on problem posing activities in mathematics course about problem posing strategies (structured problem posing, semistructured problem posing and free problem posing) and posing problems about given subject. In addition to these views, students indicated their opinions on posing problems integrated with social justice and equality issues and posing problems with different difficulty and type for the instruction process. Regarding problem posing frequency, in mathematics course, students said that less problems were posed and problems posed when mentioned in the textbook but in the instruction process almost in every lesson, problems were posed and it is stated that more importance was given than mathematics course. However, in the context of interaction through problem posing, for sociomathematics course more views were expressed than mathematics course, and views about interaction with the teacher and peer were also put forward. Therefore, the instruction might have increased the awareness of students regarding the different problem posing practices. 


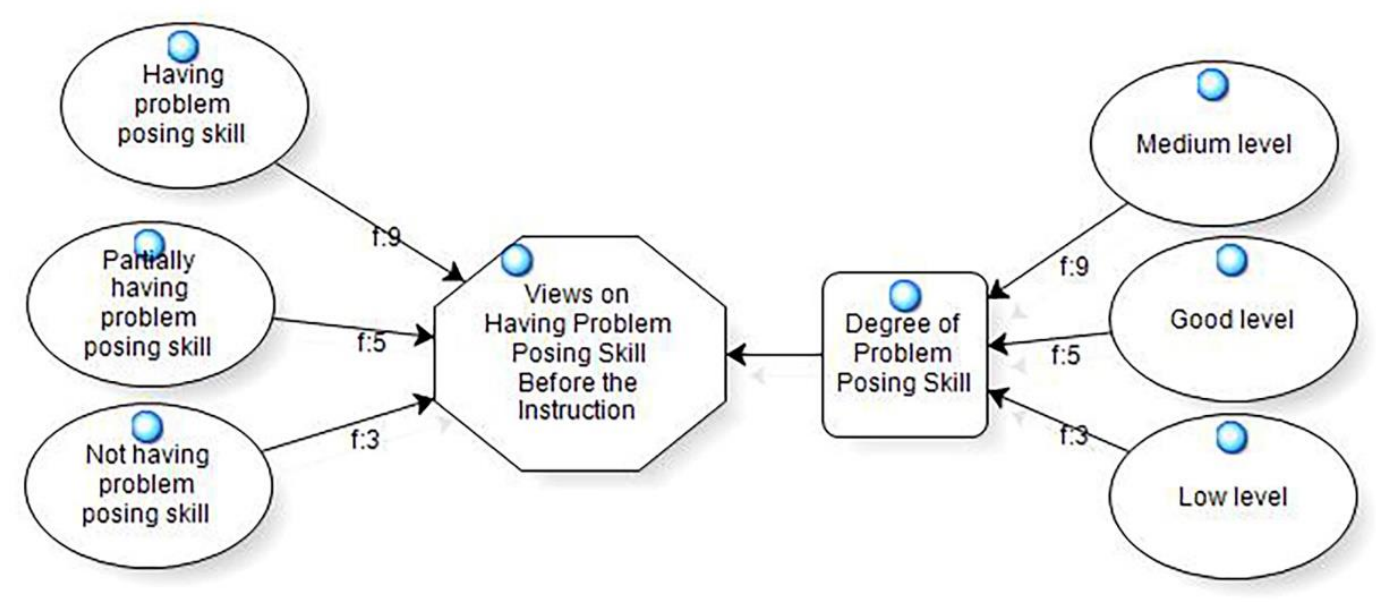

FIGURE 4. Students' views on having problem posing skill before the instruction

Students were asked whether they had the skill to pose problems and the degree of their problem posing skill and the responses were presented in Figure 4. Nine out of the seventeen students stated that they had the skill to pose problems; five stated they partially had and three stated they had not this skill at all. Besides, with regard to the degree of their problem posing skill, nine students thought that they were at medium level, five students were at good level and three students were at low level. Based on the students' evaluation of their problem posing skills, it was determined that some of them did not have problem posing skill at all, most of them thought about having problem posing skills partially and moderately and some of them had good problem posing skill before the instruction.

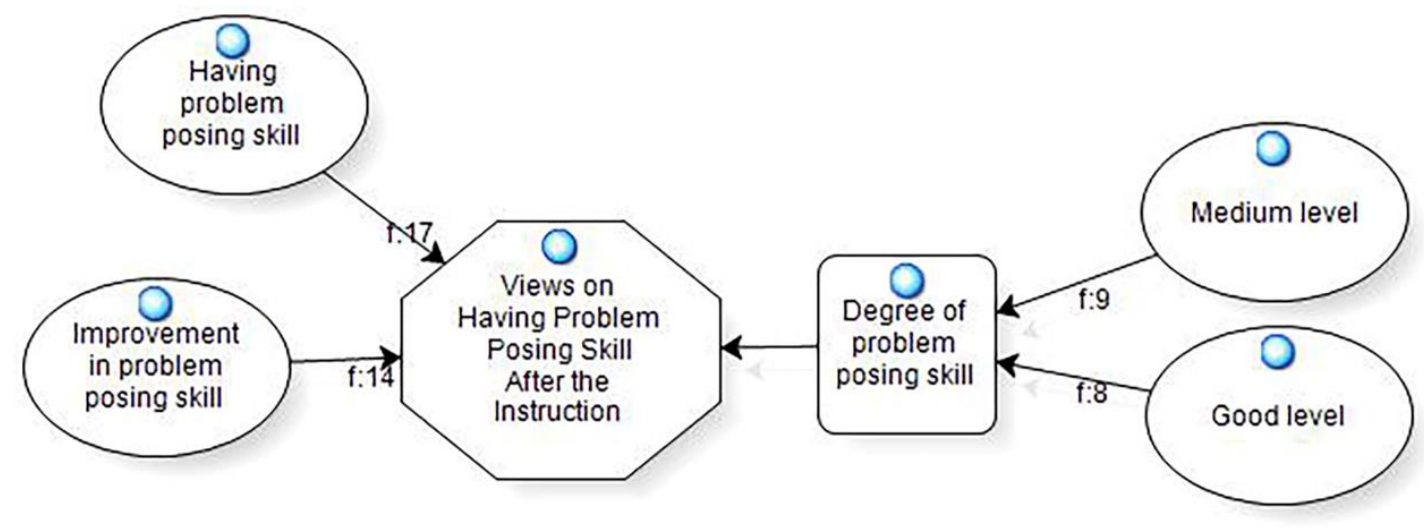

FIGURE 5. Students' views on having problem posing skill after the instruction

As for the degree of problem posing skill all students stated that they had the skill to pose problems and fourteen students stated that their problem posing skills were improved after the instruction. Besides, nine students thought that they were at medium level, eight students were at good level. Accordingly, S14 said, "Yes, we weren't posing problems before the sociomathematics course, now, I have started to pose better problems."S4 expressed his views emphasizing the effects of instruction to problem posing and solving skills as "Because my problem posing skill is improved, in this way I can easily pose and solve meaningful problems for example in proportion subject. At first I didn't understand the proportion subject but after two or three worksheets and you've showed me, I figured out how and I could." Similarly, S9 said "It used to be bad formerly... My teacher, I couldn't pose problems formerly but now I am trying to pose problems... Because you taught well, I understood the subject, therefore I can pose better problems." 
Students' views on having problem posing skills were compared before and after the instruction, nine students stated that they had the skill to pose problems, five stated they partially had and three stated that they had not at all before the instruction; after the instruction all students stated that they had problem posing skill and the majority of students indicated that they have improved their problem posing skills. Also, they said that they were in better condition and improved their problem posing skills compared to the pre-instruction process, and so it can be inferred that the instruction contributed to the problem posing skill.

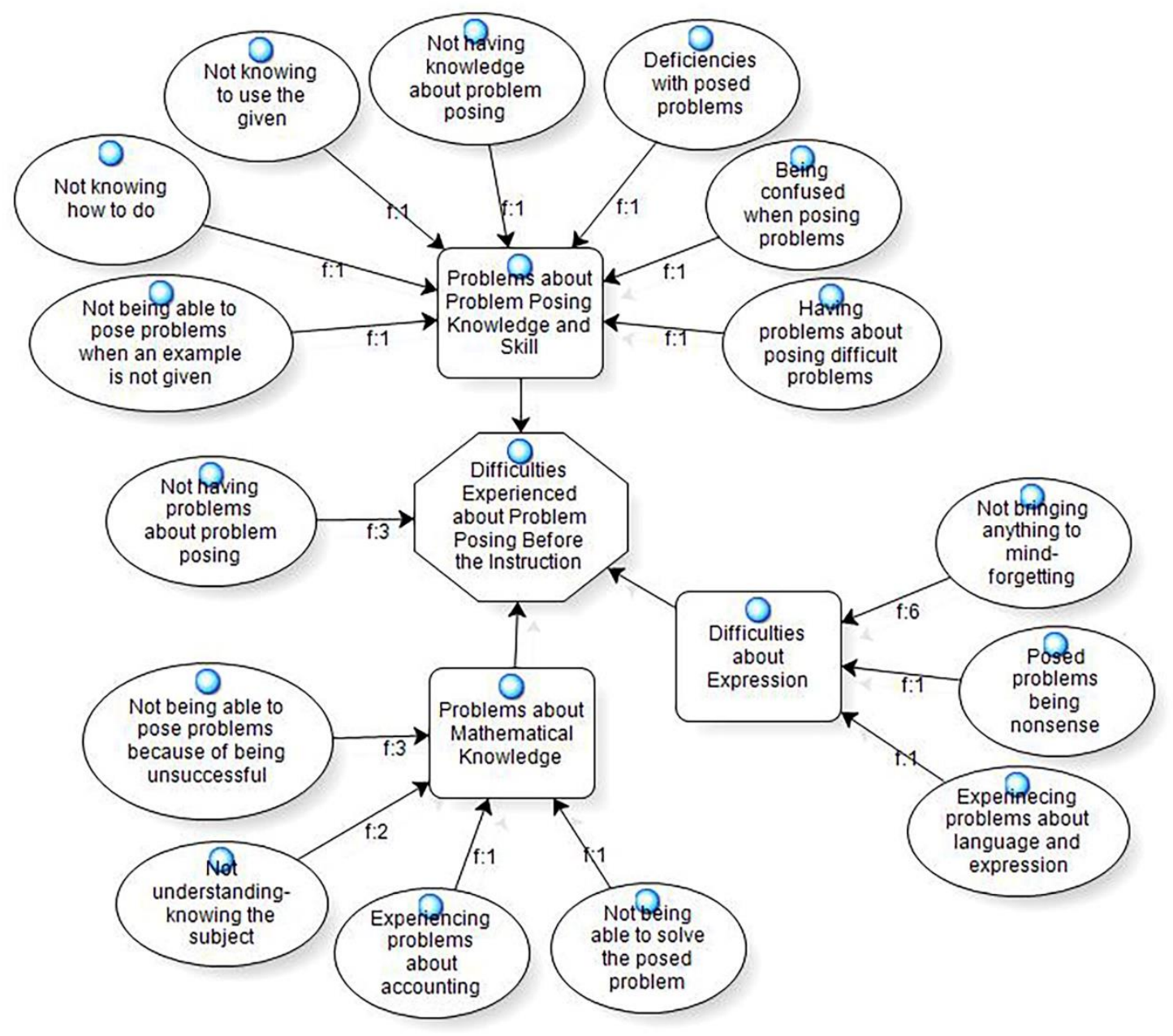

FIGURE 6. The difficulties that students experienced about problem posing before the instruction

The students were asked whether they had any difficulties in posing problems and three students stated that they had difficulties in posing a problem. The answers of students who had difficulties were presented in Figure 6. These difficulties were gathered under three themes: Difficulties about expression (f:8), problems about problem posing knowledge and skill (f:7) and problems about mathematical knowledge (f:7). The most experienced problem was about not bringing anything to mind/forgetting (f:6). However, the students also stated problems about not being able to pose problems because of being unsuccessful in mathematics (f:3) and not understanding/knowing the subject (f:2). Related to problems about problem posing knowledge and skill, S10 expressed "For example sometimes the teacher gives a little difficult so I am experiencing problems... I can do it but still when it is given a little difficult I can't do, I'm having trouble." Within problems about mathematical knowledge S1 indicated "Because I couldn't get used to mathematics, a mathematics course; I can't understand mathematics much, so I can't pose problems." Regarding difficulties about expression S9 said "My teacher, for example, when we pose problems, nothing comes to my mind." According to the views of the students, it was determined 
that the majority of the students experienced problems due to various reasons during posing problems before the instruction.

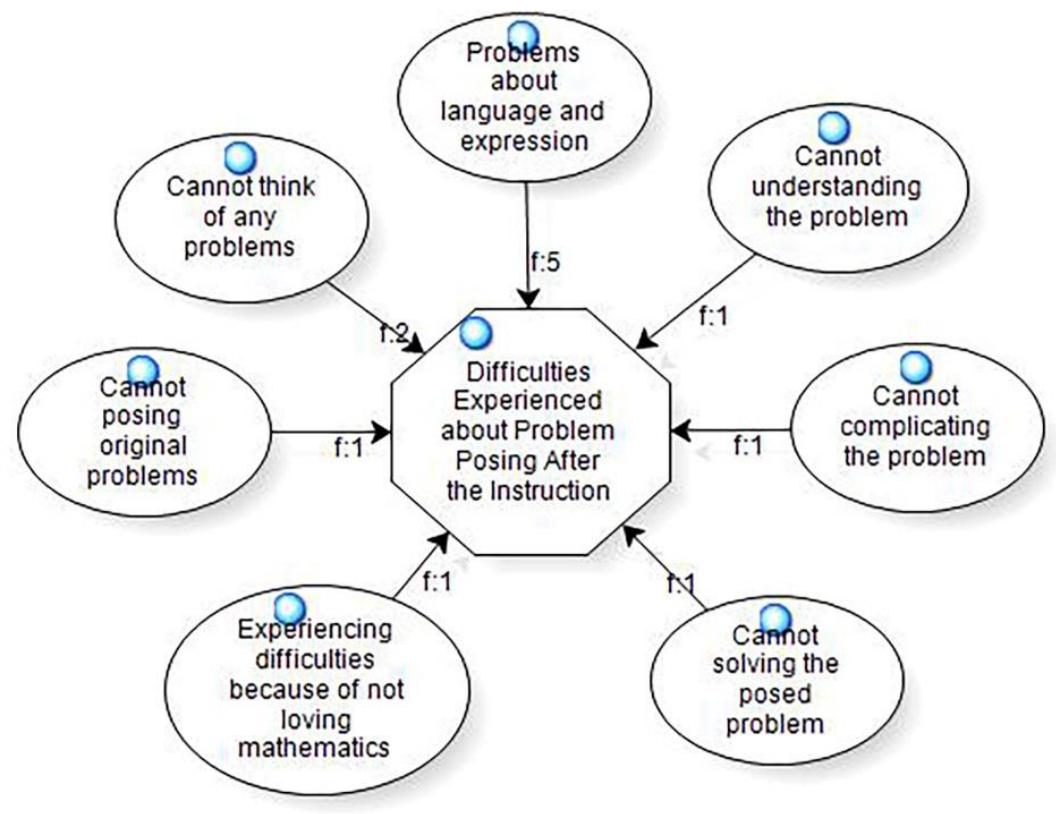

FIGURE 7. Difficulties that students experienced about problem posing after the instruction

As it is on Figure 7, with regard to difficulties experienced about problem posing, eight students stated that they don't experience any difficulties. Within the context of this dimension, the most experienced problems were about language and expression (f:5). Moreover, students also experienced problems about cannot think of any problems (f:2), cannot complicating the problem (f:1), cannot understanding the problem (f:1), cannot solving the posed problem by himself/herself (f:1), cannot posing original problem (f:1) and experiencing difficulty because of not loving mathematics (f:1). S12, who has problems with language and expression, explained these problems as "I cannot provide numbers fit exactly, in the words there can be incoherency." S16 said "I pose, I can pose but I cannot use the language, I cannot use the Turkish language when I'm posing problems, I cannot link words to each other, always there is a confusion, so anyone cannot understand usually." Again, S10 emphasized the case of not being able think of any problems and said "Sometimes I cannot recall, sometimes I don't know how to do but it comes to my mind later."

Students' views on difficulties in problem posing were compared before and after the instruction. Three students stated that they didn't experience any difficulties and there were twenty-six different problems before the instruction. But after the instruction, eight students mentioned that they didn't experience any difficulties and there were twelve different problems. After the instruction, it was revealed that fewer students experienced problems and therefore the problems decreased. Hence, it can be said that the instruction was effective in reducing and eliminating the problems experienced by students. 


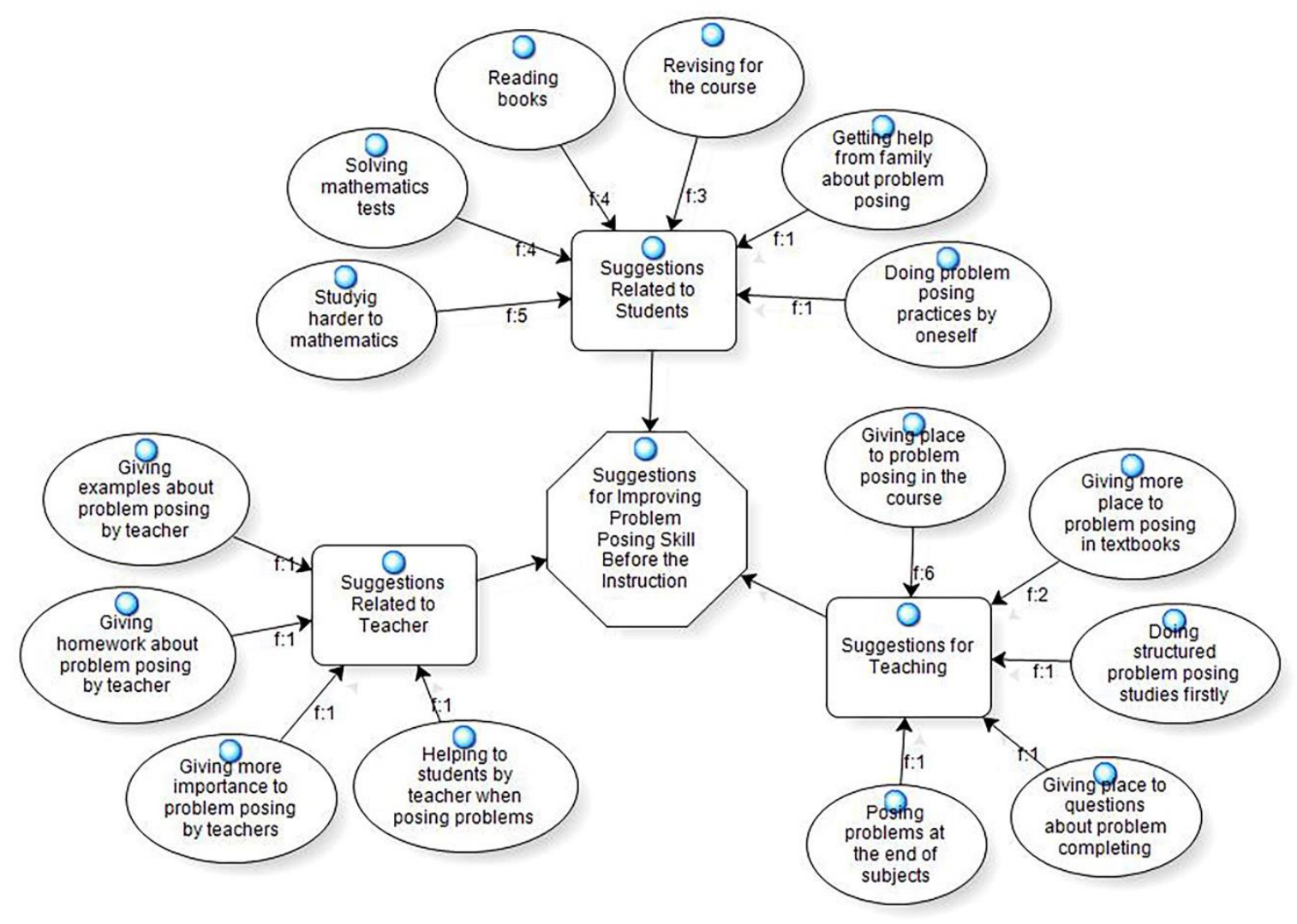

FIGURE 8. Students' suggestions for improving problem posing skill before the instruction

It is seen on Figure 8, students' suggestions for problem posing skill before the instruction were gathered under three themes: Suggestions related to students (f:16), suggestions for teaching (f:11) and suggestions related to teacher (f:4). The most recurring views in this context were about giving place to problem posing (f:6), studying harder to mathematics (f:5), solving mathematics tests (f:4), reading books (f:4) and revising for the course (f:3). With respect to giving more place to problem posing, S3 stated "More problems have to be posed, for example, if it continues two hours, it must enhance to three hours." Concerning suggestions related to students S8 indicated "By writing numerical data by ourselves, we can pose problems with them." In the context of suggestions related to teacher S2 said "Also teachers need to focus on problem posing." 


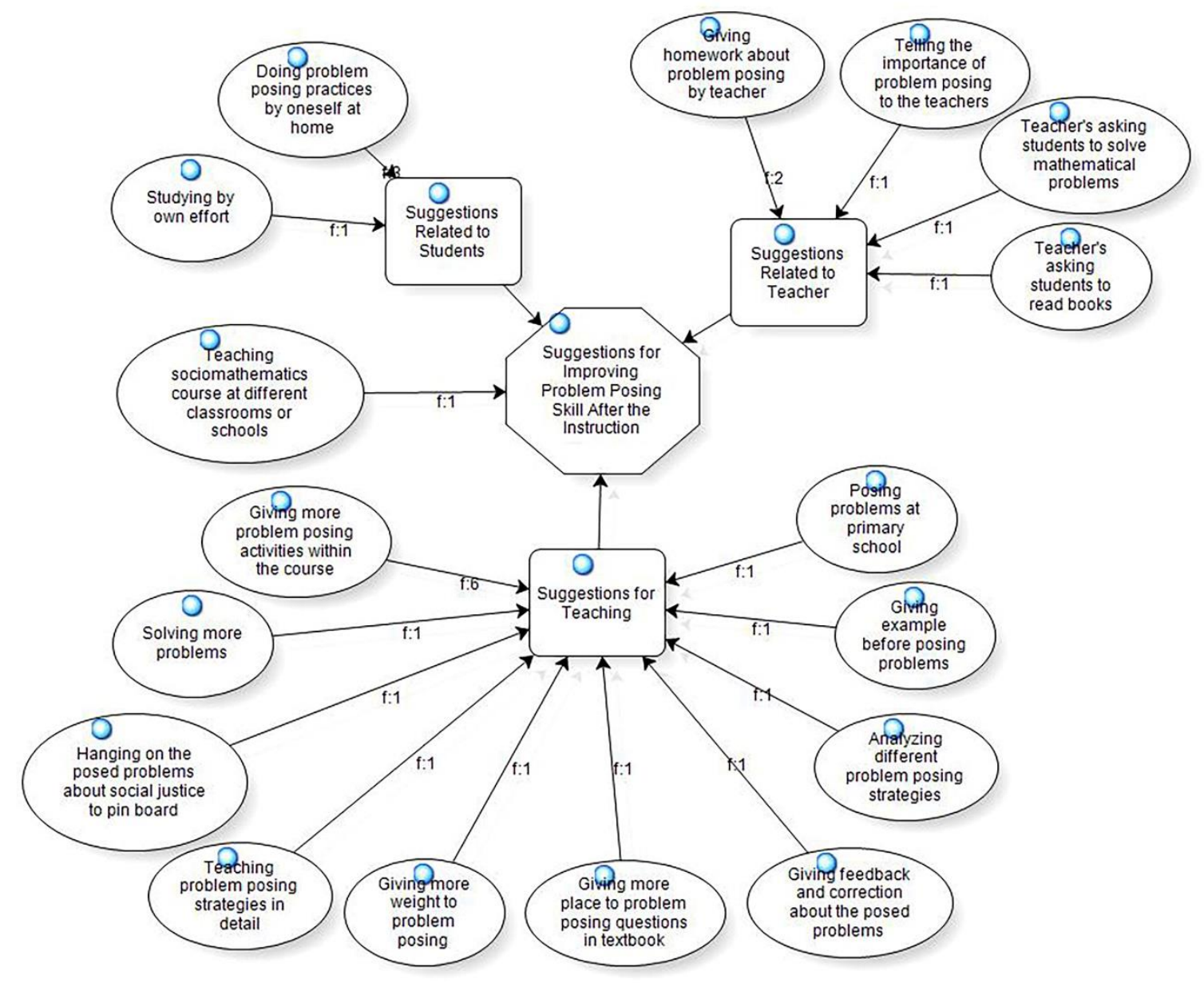

FIGURE 9. Students' suggestions for improving problem posing skill after the instruction

It is shown on Figure 9, after the instruction students' suggestions for improving problem posing skill were gathered under three themes: Suggestions for teaching (f:16), suggestions related to teacher (f:4) and suggestions related to students (f:4). Regarding suggestions for teaching theme, there were suggestions mostly about giving more problem posing activities within the course (f:6). Moreover, students presented suggestions also about solving more problems (f:2), hanging on the posed problems about social justice to the pin board (f:1), teaching problem posing strategies in detail (f:1), giving more weight to problem posing (f:1), giving more place to problem posing questions in the textbook (f:1), giving feedback and correction about the posed problems (f:1), analyzing different problem posing strategies (f:1), giving example before posing problems (f:1) and posing problems at primary school (f:1). Within this context S7 presented suggestions as "More problems can be posed, and then, for example, problem posing strategies can be teached in detail." For suggestions related to teacher, giving homework about problem posing by teacher (f:2) was the most frequently emphasized one. Furthermore, suggestions were presented about telling the importance of problem posing to the teachers (f:1), teacher's asking students to solve mathematical problems (f:1) and teacher's asking students to read books (f:1). Concerning this theme, S5 said "More problem posing questions can be added to textbooks and it can be written to be done definitely, actually, because, there was a problem again in our mathematics course a few days ago, but we couldn't solve, we passed it directly. Teachers should be told that such things should definitely be done. So, after all, in some situations problem posing can confront to us, it increased our problem solving skill, so, such things can be done."Within suggestions related to students, there were suggestions mostly about doing problem posing practices by oneself at home (f:3). There was also suggestion about studying by own effort (f:1). In this context S16 stated "We need to make use of our free time, when we have nothing to do, we can write one or two problems so we can 
adapt ourselves." Other than these themes, a student presented his suggestion as teaching sociomathematics course at different classrooms or schools. In relation to that, S17 said "The course you taught can be taught in different places. I think about it."

Students' suggestions for improving problem posing skill were compared before and after the instruction, there were three themes both before and after the instruction: Suggestions for teaching, suggestions related to teacher, suggestions related to students. It was determined that the suggestions offered by the students before and after the instruction were similar in general terms; after the instruction, it was seen that the number of suggestions for teaching increased while the number of suggestions related to students decreased. In the context of suggestions related to students, students offered suggestions about revising for the course, solving tests, reading books, getting support from family before the instruction. But after the instruction students didn't offer these suggestions but they talked about the student's own efforts and suggestions for developing the problem posing skill by oneself. The reason for this difference could be explained as students' starting to think that they can improve problem posing skill with their own efforts. After instruction, unlike before it, in the context of suggestions for teaching, students offered suggestions about problem posing strategies, posing problems about social justice issues and starting to pose problems at primary school. These suggestions gave rise to the idea that students were getting more aware of the problem posing.

During analysis of the data, a theme which was not included in the interview questions was emerged regarding the benefits of problem posing. Views related to this theme were given on Figure 10.

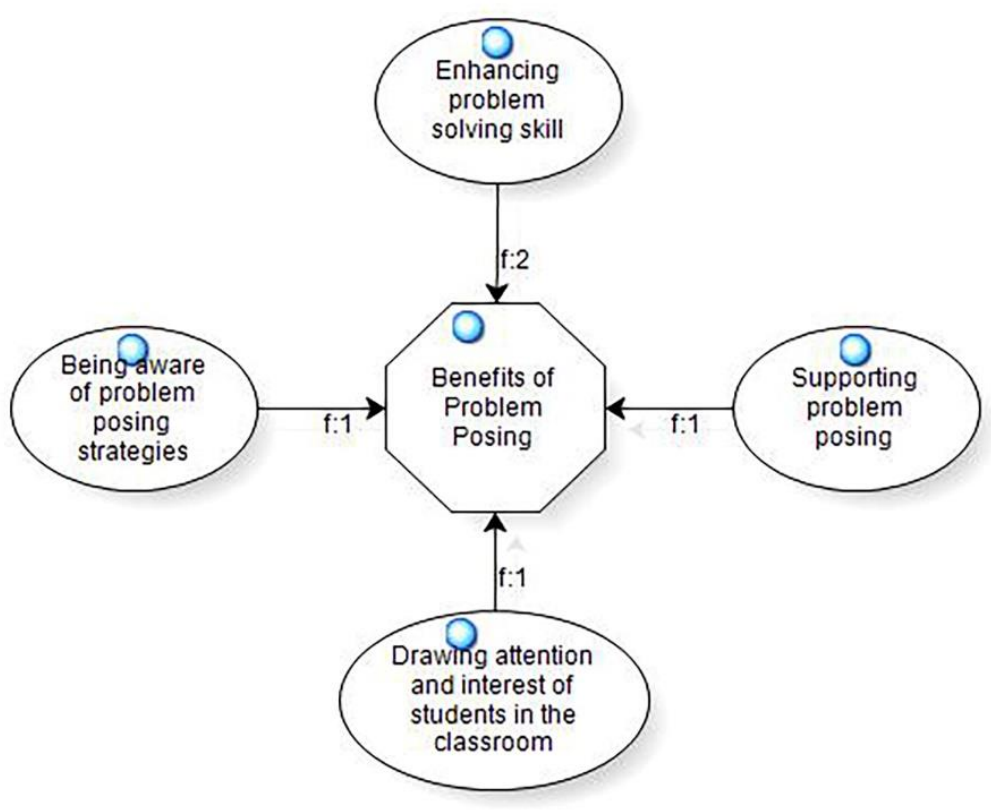

FIGURE 10. Students' views on benefits of problem posing

As seen on Figure 10, after the instruction students presented different benefits of problem posing. Within this theme, it was stated that problem posing mostly contributes to enhance problem solving skill (f:2). In addition, it was stated that there were benefits such as being aware of problem posing strategies (f:1), supporting problem posing (f:1) and drawing attention and interest of students in the classroom (f:1). Related to this theme S17 expressed his views focusing on drawing attention and interest of students as "For example, how can I say, our friend poses, writes on board, different people solve. Thus, for example, students not paying attention to course, many in the classroom, refocus on the course when something fun is done. Now our classroom is better than the formerly because of this." S8 stated "For example, you give problems, we are trying to pose problems. We are aware of each subject, that is, about each type of problems, you give 
different types of problems, when we do like it, so we reinforce all." S5 focused on the benefits to problem solving skill and stated "Problem posing improves the problem solving skill."

\section{DISCUSSION AND CONCLUSIONS}

Before the instruction, it was indicated that problem posing skill of students were not adequate in accordance with the quantitative data obtained from the problem posing skill test for the improvement of problem posing skill. Besides, it was pointed out that there was a significant difference between the pre- and post-test scores of participant students in favour of post-test scores. Therefore, it is possible to conclude that the level of students' problem posing skill increased significantly thanks to the instruction. In this respect, in the courses of mathematics and mathematics practices, it may be suggested that various practices or instructions should be carried out to make students understand the importance of mathematics in social life and improve their mathematical skills such as problem posing.

According to the qualitative data regarding problem posing skills, a comparison of pre-instruction and post-instruction opinions may be useful to see the progress of problem posing skill. In line with this, within the framework of the same themes created in the interviews, the sub-themes created before and after the instruction were compared. When the opinions of students about having problem posing skills before and after the instruction were compared, nine of the students described their problem posing skills as medium, five of them as good and three of them as bad before the instruction while after the instruction, nine of the students described their problem posing skills as medium and eight of them as good. On the other hand, before the instruction, nine of the students stated that they had problem posing skills, five of them stated that they had partial problem posing skill, and three of them stated that they did not have at all whereas after the instruction, all of the students stated that they had problem posing skills. Furthermore, almost all of the students indicated that their problem posing skills improved. Accordingly, it could be asserted that the instruction carried out had an effect on the improvement of students' problem posing skill. Whilst there have not been any studies, which are integrated with social issues or interdisciplinary, on the improvement of problem posing skill, the results of studies on improving the problem posing skill in the field of mathematics in the literature show that the instruction related to problem posing increases the problem posing skill of students (English, 1997; Turhan \& Güven, 2014, Yıldız, 2014, Kojima, Miwa \& Matsui, 2015). Therefore, it can be said that it is possible to improve the problem posing skill of students, who have encountered very few problem posing studies before, through learning experiences designed for this purpose. In this sense, when the contributions of the instruction carried out within the study are considered, it can be suggested to reflect these practices on the curricula of the mathematics course and mathematics practices course.

Related to the problems experienced with regard to problem posing, before the instruction, the problems were gathered under sub-themes such as problems related to the expression in problem posing, mathematics knowledge, problem posing knowledge and skills. However, three students stated that they did not have any problems with problem posing. After the instruction, it was found out that the problems experienced during problem posing were also gathered under the same sub-themes such as problems related to the expression in problem posing, mathematics knowledge, problem posing knowledge and skills. Unlike before the instruction, eight students mentioned that they did not have any difficulties in problem posing, after the instruction. Accordingly, it could be claimed that the problems experienced within problem posing decreased thanks to the instruction. Nevertheless, the problems with expression in problem posing still partially continued. It is thought that this problem could be solved by focusing on the language and expression skills besides the instruction, and therefore it may be more useful to expand the instruction process by cooperating with the domain experts in Turkish language education and with Turkish language teachers. From this point of view, when it is considered that the most common problems in this study were the difficulties in problem posing and the deficiencies in language and expression while posing problems, it can be suggested to carry out activities for the 
improvement of language and expression skills of students. Besides, since this problem could not be completely eliminated during the instruction, it is possible to design a longer practice process. It is indicated that students, who have encountered very few problem posing studies before, have difficulties in establishing a mathematical structure in problem posing studies (Kojima, Miwa \& Matsui, 2015), and they do not have any method to follow in problem posing studies on a given situation (Cai \& Hwang, 2002). Similarly, some students do not have any strategy for new problem posing and have difficulties in explaining what way they follow in problem posing (Van Harpen \& Presmeg, 2013). Besides, in the study carried out by Katrancı and Şengül (2015), it was put forward that there were problems such as failure to create a problem, inadequacy of data, inability to write creative problems, and inability to provide an integer for the solution. Moreover, as a result of the study conducted by Arıkan and Ünal (2013b), it was determined that during problem posing studies some students could not pose appropriate problems for the desired situation, misconceptions showed up, and they did not use the Turkish language well. Similarly, in the study conducted by Kılıç (2013b), it was observed that students had problems such as using missing data, using decimal numbers, writing exercises, setting up problems for different subjects and operations during the problem posing study required four operations with natural numbers. From the results of these studies, it can be said that students have problems and difficulties in problem posing studies. Again, in the instruction process, it was found out that students experienced similar problems with the problems encountered in these studies. However, these difficulties and problems experienced by students were reduced during the instruction. In this respect, when effective practices are performed to improve problem posing skills, consequently these problems can be reduced.

Lavy and Bershadsky (2003) point out that students are not self-confident enough to make considerable changes with the given problem and are satisfied with their superficial changes in problem posing studies. In addition, English (1998) states that students with different levels of achievement create different answers in problem posing and posed problems at different difficulty levels from a structural and procedural point of view. Furthermore, Cai et al. (2015) argue that the students' low level of achievement in problem posing might be due to the lack of experience in problem posing in general. It shows that the reasons underlying the mentioned problems originate from the lack of self-confidence in students, the presence of students with different levels of achievement in the classroom, and the lack of experience in problem posing. Problems similar to these problems were encountered during the instruction process, and they were mainly discussed within the context of problems related to problem posing knowledge and skills. Yet, a significant decrease in the number of students having difficulty in problem posing at the end of the process indicates the effectiveness of the instruction in this regard.

Regarding the suggestions to improve the problem posing skill of students, it was seen that before the instruction, suggestions were mostly made for students, and also for teaching and teachers. After the instruction, it was observed that suggestions were made mostly for teaching, and also for teachers and students. In addition to this, in this context, a student suggested teaching sociomathematics in different classes and schools. It was found out that after the instruction fewer suggestions were presented for students compared to before the instruction. This might be because students thought that they could improve problem posing skill on their own before the instruction. On the other hand, after the instruction, they possibly thought that they could improve their problem posing skill by allocating much more time for it. This brought up the idea that within the scope of the mathematics and mathematics practices courses, teachers do not perform enough activities for problem posing. The reason for this could be examined by the studies on teachers and pre-service teachers in the literature.

In the study carried out by Kar and Işik (2015), it was revealed that teachers experienced problems in problem posing studies because of the difficulties due to the linguistic, conceptual dimensions, and their habits within teaching process. In the study by Tertemiz and Sulak (2013), it is also indicated that teachers gave not enough place to problem posing studies and they have to gain proficiency in problem posing. In line with this, it seems that teachers also have problems and difficulties in teaching problem posing effectively. It is considered that teachers, whose problem posing skills and problem posing teaching competences are low, may also be inadequate 
in improving the problem posing skills of students. In this regard, Rosli et al. (2015) also suggested that teacher trainers should ensure concrete educational experiences by making problem solving and problem posing activities interesting. Teachers may tend to give more place to problem posing studies in their courses by increasing their awareness of problem posing with the training they will receive on problem posing teaching. Accordingly, the recommendations of students for teaching and teachers can be met.

In addition to all these, unlike before the instruction, students also expressed the benefits of problem posing after the instruction. With regard to these mentioned opinions, it could be inferred that the implemented instruction contributed to the improvement of problem posing skills of students. According to the students' opinions, the presence of studies indicating that problem posing studies improve the problem posing skill (Cai \& Hwang, 2003; Silver, 2013; Cai et al., 2015; Chen, Van Dooren \& Verschaffel, 2015; Innoka, Shimomura \& Kanno, 2015) and reinforce problem posing (English, 1997; Turhan \& Güven, 2014; Yıldız, 2014; Kojima, Miwa, Matsui, 2015) in the literature supports these opinions. Although a similar study in which mathematics teaching is integrated with sociomathematical subjects and which aims directly to improve problem posing skill has not been encountered, there are studies that include social justice and equality subjects in mathematics education. When these studies were examined, it was found out that discussing social justice and equality subjects in the mathematics course increases mathematical comprehension (Alexander, 2001), ensures the comprehension of the importance of mathematics and closeness to mathematics (Johnson, 2005), increases the participation of the class (Brantlinger, 2007; Voss, 2015), contributes to the awareness that mathematics is related to real life (Jang, 2010), increases attitudes toward mathematics (Petric, 2011; Voss, 2015), affects learning positively (Voss, 2015), and ensures that more value is given to mathematics (Harper, 2017). Based on this, it could be said that including social justice and equality subjects within the mathematics course contributes to the mathematics course from cognitive and affective aspects.

\section{ACKNOWLEDGEMENTS}

This study was supported by Çukurova University Scientific Research Projects Unit (SDK-20142862).

\section{REFERENCES}

Akkan, Y., Çakıroğlu, Ü. \& Güven, B. (2009). İlköğretim 6. ve 7. sınıf öğrencilerinin denklem oluşturma ve problem kurma yeterlilikleri. Mehmet Akif Ersoy University Journal of Education Faculty, 9(17), 41-55.

Alexander, P. T. (2001). Math and social justice: a capstone course for undergraduates. Unpublished doctoral dissertation. University of California, Santa Barbara.

Allen, A. F. (2003). Integrating themes of social justice and equity into a middle school mathematics classroom. Unpublished doctoral dissertation. Indiana University, Indianapolis.

Altrichter, H., Feldman, A., Posch, P. \& Somekh, B. (2008). Teachers investigate their work: An introduction to action research across the professions. (2nd ed.). Oxon: Routledge.

Arıkan, E. E. \& Ünal, H. (2013a). Problem posing and problem solving ability of students with different socio ecenomics levels. International Journal Social Science Research, 2(2), 1625.

Arıkan, E. E. \& Ünal, H. (2013b). İlköğretim 2. sınıf öğrencilerinin matematiksel problem kurma becerilerinin incelenmesi. Amasya Üniversitesi Eğitim Fakültesi Dergisi, 2(2), 305-325.

Arıkan, E. E. \& Ünal, H. (2014). Development of the structured problem posing skills and using metaphoric perceptions. European Journal of Science and Mathematics Education, 2(3), 155-166.

Arıkan, E. \& Ünal, H. (2015). An investigation of eighth grade students' problem posing skills (Turkey sample). International Journal of Research in Education and Science, 1(1), 23-30.

Balı, A. Ș. (2001). Çokkültürlülük ve sosyal adalet. Konya: Çizgi. 
Baş, T. \& Akturan, U. (2008). Nitel araştırma yöntemleri: Nvivo ile nitel veri analizi, örnekleme, analiz, yorum. Ankara: Seçkin.

Bonotto, C. (2010). Engaging students in mathematical modelling and problem posing activities. Journal of Mathematical Modelling and Application, 1(3), 18-32.

Brantlinger, A. M. (2007). Geometries of inequality: teaching and researching critical mathematics in a low-Income urban high school. Unpublished doctoral dissertation. Northwestern University, Illinois.

Cai, J. \& Hwang, S. (2002). Generalized and generative thinking in US and Chinese students' mathematical problem solving and problem posing. Journal of Mathematical Behavior, 21(2002), 401-421.

Cai, J. \& Hwang, S. (2003). A perspective for examining the link between problem posing and problem solving. International Group for the Psychology of Mathematics Education, 3, 103-110.

Cai, J., Hwang, S., Jiang, C. \& Silber, S. (2015). Problem-posing research in mathematics education: some answered and unanswered questions. In F. M. Singer, N. F. Ellerton \& J. Cai (Eds.), Mathematical problem posing: from research to effective practice (pp.3-34). New York: Springer.

Cai, J., Moyer, J. C., Wang, N., Hwang, S., Nie, B. \& Garber, T. (2013). Mathematical problem posing as a measure of curricular effect on students' learning. Educational Studies in Mathematics, 83(1), 57-69.

Chen, L., Van Dooren, W. \& Verschaffel, L. (2015). Enhancing the development of Chinese fifthgraders' problem-posing and problem-solving abilities, beliefs, and attitudes: a design experiment. In F. M. Singer, N. F. Ellerton \& J. Cai (Eds.), Mathematical problem posing: from research to effective practice (pp.309-329). New York: Springer.

Creswell, J. W. (2013). Qualitative inquiry \& research design: choosing among five approaches (3rd ed.). Los Angeles: Sage Publications.

Çıldır, S. \& Sezen, N. (2011). Skill levels of prospective physics teachers on problem posing. Hacettepe University Journal of Education Faculty, 40, 105-116.

Devers, K. J. \& Frankel, R. M. (2000). Study design in qualitative research - 2: sampling and data collection strategies. Education for Health, 13(2), 263 - 271.

Downe - Wamboldt, B. (1992). Content analysis: Method, applications, and issues. Health Care for Women International, 13(3), 313-321.

Ellerton, N. F. (2013). Engaging pre-service middle school teacher-education students in mathematical problem posing: Development of an active learning framework. Educational Studies in Mathematics, 83(1), 87-101.

English, L. D. (1997). The development of fifth grade children's problem posing abilities. Educational Studies in Mathematics, 34, 183-217.

English, L. D. (1998). Children's problem posing within formal and informal contexts. Journal for Research in Mathematics education, 29(1), 83-106.

English, L. D. \& Watson, J. M. (2015). Statistical literacy in the elementary school: opportunities for problem posing. In F. M. Singer, N. F. Ellerton \& J. Cai (Eds.), Mathematical problem posing: from research to effective practice (pp.241-256). New York: Springer.

Freebody, P. (2004). Qualitative research in education (1st ed.) London: Sage Publications.

Gonzalez, L. (2009). Teaching mathematics for social justice: reflections on a community of practice for urban high school mathematics teachers. Journal of Urban Mathematics Education, 2(1), 22-51.

Greenwood, D. J. \& Levin, M. (2007). Introduction to action research: social research for social change (2nd ed.). California: Sage Publications.

Gutstein, E. (2003). Teaching and learning mathematics for social justice in urban, Latino school. Journal for Research in Mathematics Education, 34(1), 37-73.

Gutstein, E. (2006). Reading and writing the world with mathematics - toward a pedagogy for social justice. New York: Routledge. 
Gutstein, E., Middleton, J. A., Fey, J. T., Larson, M., Heid, M. K., Dougherty, B., et al. (2005). Equity in school mathematics education: how can research contribute? Journal for Research in Mathematics Education, 36(2), 92-100.

Harpen, X. Y. \& Sriraman, B. (2013). Creativity and mathematical problem posing: an analysis of high school students' mathematical problem posing in China and the USA. Educational Studies in Mathematics, 82(2), 201-221. doi: 10.1007/s10649-012-9419-5

Harper, F. K. (2017). Coming to understand the big issues: remaking meaning of social justice through mathematics across the school year. In A. Chronaki (Ed.), Mathematics Education and Life at Times of Crisis, 2, Proceedings of the Ninth International Mathematics Education and Society Conference (pp. 513-521). Volos: University of Thessaly Press.

Hart, L. E. (2003). Some directions for research on equity and justice in mathematics education. In L. Burton (Ed.), Which way social justice in mathematics education? (pp.27-49) (1st ed.). London: Praeger Publishers.

Innoka, M., Shimomura, T. \& Kanno, E. (2015). Problem posing in the upper grades using computers. In F. M. Singer, N. F. Ellerton \& J. Cai (Eds.), Mathematical problem posing: From research to effective practice (pp.257-272). New York: Springer.

Işık, C. \& Kar, T. (2012). Sınıf öğretmeni adaylarının problem kurma becerileri. Mehmet Akif Ersoy University Journal of Education Faculty, 12(23), 190-214.

Işık, A. Çiltaş, A. \& Kar, T. (2012). Problem kurma temelli öğretimin farklı sayı algılamasına sahip öğrencilerin problem çözme başarılarına etkisi. Pegem Journal of Education and Instruction, 2(4), 71-80.

Jang, B. S. (2010). Teaching for social justice with students from privileged groups: integrating social justice into middle school curriculum. Unpublished doctoral dissertation, Boise State University, Boise.

Johnson, J. D. (2005). Instructional implications of social justice pedagogy on the teaching of mathematics. Unpublished doctoral dissertation. The Florida State University, Florida.

Johnson, R. L., Penny, J. \& Gordon, B. (2000). The relation between score resolution methods and interrater reliability: an empirical study of an analytic scoring rubric. Applied Measurement in Education, 13(2), 121-138.

Kar, T. \& Işık, A. (2015). Ortaokul matematik öğretmenlerinin kesirlerle çıkarma işlemine yönelik problem kurma becerilerinin incelenmesi. Dicle University Journal of Ziya Gökalp Faculty of Education, 24(2015), 243-276. doi: 10.14582/DUZGEF.496

Katrancl, Y. \& Şengül, S. (2015). Semi-structured problem posing cases of prospective mathematics teachers: experiences and suggestions. International Journal on New Trends in Education and Their Implications, 6(2), 56-69.

Kemmis, S. \& Wilkinson, M. (1998). Participatory action research and the study of practice. in B. Athew, S. Kemmis \& P. Weeks (Eds.). Action research in practice - Partnerships for social justice education (1st ed.) (pp. 21-37). London: Routledge.

Kılıç, Ç. (2012). Determination issues that primary teachers encountered during problem posing activities and their solution suggestions: Eliminating pedagogic obstacles. Adryaman University Journal of Social Sciences Institute, 5(10), 243-264.

Kılıç, Ç. (2013a). Pre-service primary teachers' free problem posing performances in the context of fractions: an example from Turkey. Asia-Pacific Education Researcher, 22 (4), 677-686.

Kılıç, Ç. (2013b). İlköğretim öğrencilerinin doğal sayılarla dört işlem gerektiren problem kurma etkinliklerindeki performanslarının belirlenmesi. Dicle University Journal of Ziya Gökalp Faculty of Education, 20(2013), 256-274.

Klaassen, K. \& Doorman, M. (2015). Problem posing as providing students with content-specific motives. In F. M. Singer, N. F. Ellerton \& J. Cai (Eds.), Mathematical problem posing: from research to effective practice (pp. 215-240). New York: Springer.

Koestler, C. (2010). (Re)envisioning mathematics education: examining equity and social justice in an elementary mathematics methods course. Unpublished doctoral dissertation. University of Wisconsin, Madison. 
Kojima, K., Miwa, K. \& Matsui, T. (2015). Experimental study of learning support through examples in mathematical problem posing. Research and Practice in Technology Enhanced Learning, 10(1), 1-18. doi: 10.1007/s41039-015-0001-5

Kutlu, Ö., Doğan, C. D. \& Karakaya, İ. (2010). Öğrenci başarısının belirlenmesi: performansa ve portfolyoya dayalı durum belirleme. Ankara: Pegem.

Kwek, M. L. (2015). Using problem posing as a formative assessment tool. In F. M. Singer, N. F. Ellerton \& J. Cai (Eds.), Mathematical problem posing: From research to effective practice (pp.273-292). New York: Springer.

Lavy, I. \& Bershadsky, I. (2003). Problem posing via "what if not?" strategy in solid geometry - a case study. Journal of Mathematical Behavior, 22, 369-387.

Marshall, M. N. (1996). Sampling for qualitative research. Family Practice Oxford University Press, 13(6), $522-525$.

McKernan, J. (1996) Curriculum action research: $A$ handbook of methods and resources for the reflective practitioner (2nd ed.). Oxon: Routledge.

McNiff, J. (2013). Action research: Principles and practice (3rd ed.). Oxon: Routledge.

McNiff, J. \& Whitehead, J. (2010). You and your action research project. Oxon: Routledge.

Milinković, J. (2015). Conceptualizing problem posing via transformation. In Mathematical problem posing: from research to effective practice, F. M. Singer, N. F. Ellerton \& J. Cai (Eds.), (pp.47-70). New York: Springer.

Ministry of National Education, Turkey. (2013a). Secondary school and imam hatip secondary school mathematics practices curriculum (5th, 6th, 7th and 8th grades). Retrieved on February 9, 2014, from http://ttkb.meb.gov.tr/dosyalar/programlar/ilkogretim/matematikuygulamalari_orta okul.pdf.

Ministry of National Education, Turkey. (2013b). Secondary school and imam hatip secondary school mathematics curriculum (5th, 6th, 7th and 8th grades). Retrieved on February 9, 2014, from http://ttkb.meb.gov.tr/dosyalar/programlar/ilkogretim/matematikuygulamalari_orta okul.pdf.

Morse, J. M., Barrett, M., Mayan, M., Olson, K. \& Spiers, J. (2002). Verification strategies for establishing reliability and validity in qualitative research. International Journal of Qualitative Methods, 1(2), 13-22.

Noyes, A. (2007). Rethinking school mathematics (1st ed.). London: Paul Chapman Publishing.

Osana, H. P. \& Pelczer, I. (2015). A review on problem posing in teacher education. In F. M. Singer, N. F. Ellerton \& J. Cai (Eds.), Mathematical problem posing: from research to effective practice (pp. 469-492). New York: Springer.

Patton, M. Q. (2002). Qualitative research \& evaluation methods (3rd ed.). Thousand Oaks: Sage Publications.

Peterson, B. (2002). Planting seeds of solidarity. In B. Bigelow \& B. Peterson, (Eds.), Rethinking globalization - teaching for justice in an unjust world (pp. 18-28). Milwaukee: Rethinking Schools Publication.

Peterson, B. (2007a). Teaching for social justice: One teacher's journey. In W. Au, B. Bigelow \& S. Karp (Eds.). Rethinking our classrooms: Teaching for equity and justice Volume-1 (2nd ed.). (pp. 28-34). Milwaukee: Rethinking Schools.

Peterson, B. (2007b). Teaching math across the curriculum. In W. Au, B. Bigelow \& S. Karp (Eds.). Rethinking our classrooms: Teaching for equity and justice Volume-2 (2nd ed.). (pp. 8488). Milwaukee: Rethinking Schools.

Petric, M. (2011) Reform in mathematics education: "what do we teach for and against?" Unpublished doctoral dissertation. Montclair State University, Montclair.

Rosli, R., Capraro, M. M., Goldsby, D., Gonzales, E., Onwuegbuzie, A. J. \& Capraro, R. M. (2015). Middle-grade preservice teachers' mathematical problem solving and problem posing. In F. M. Singer, N. F. Ellerton \& J. Cai (Eds.), Mathematical problem posing: from research to effective practice (pp.333-354). New York: Springer. 
Schniedewind, N., \& Davidson, E. (2006). Open minds to equality: A sourcebook of learning activities to affirm diversity and promote equity. Milwaukee: Rethinking Schools.

Silver, E. A. (1997). Fostering creativity through instruction rich in mathematical problem solving and problem posing. ZDM, 29(3), 75-80.

Silver, E. A. (2013). Problem-posing research inmathematics education: looking back, looking around, and looking ahead. Educational Studies in Mathematics, 83, 157-162.

Singer, F. M. \& Voica, C. (2015). Is problem posing a tool for identifying and developing mathematical creativity? In F. M. Singer, N. F. Ellerton \& J. Cai (Eds.), Mathematical problem posing: from research to effective practice (pp. 141-176). New York: Springer.

Siswono, T. Y. E. (2010). Leveling students' creative thinking in solving and posing mathematical problem. Journal on Mathematics Education, 1(1), 17-40.

Skowmose, O. \& Nielsen, L. (1996). Critical mathematics education. in A. J. Bishop, K. Clements, C. Keitel, J. Kilpatrick \& C. Laborde (Eds.) International handbook of mathematics education - part 2 (pp. 1250-1288). Dordrecht: Kluwer Academic Publishers.

Solórzano, L. S. (2015). Problem-posing as a didactic resource in formal mathematics courses to train future secondary school mathematics teachers. Journal of Technology and Science Education, 5(2), 64-74. doi: 10.3926/jotse.141

Spielman, L. J. (2008). Equity in mathematics education: unions and intersections of feminist and social justice literature. ZDM Mathematics Education, 40, 647-657.

Stickles, P. R. (2006). An analysis of secondary and middle school teacher's mathematical problem posing. Unpublished doctoral dissertation, Indiana University, Indiana.

Şengül, S. \& Katrancl, Y. (2014). Structured problem posing cases of prospective mathematics teachers: experiences and suggestions. International Journal on New Trends in Education and Their Implications, 5(4), 190-204.

Tanase, M. \& Lucey, T. A. (2015). Interdisciplinary connections: teaching mathematics for social justice and financial literacy. Journal of Mathematics \& Culture, 9(1), 81-118.

Tertemiz, N. \& Sulak, S. E. (2013). İlköğretim beşinci sınıf öğrencilerinin problem kurma becerilerinin incelenmesi. İlkögrretim Online, 12(3), 713-729.

Toluk-Uçar, Z. (2009). Developing pre-service teachers understanding of fractions through problem posing. Teaching and Teacher Education, 25(2009), 166-175.

Turhan, B. \& Güven, M. (2014). Problem kurma yaklaşımıyla gerçekleştirilen matematik öğretiminin problem çözme başarısı, problem kurma becerisi ve matematiğe yönelik görüşlere etkisi. Çukurova Üniversitesi Eğitim Fakültesi Dergisi, 43(2), 217-234. doi:10.14812/cufej.2014.021

Van Harpen, X. Y. \& Presmeg, N. C. (2013). An investigation of relationships between students' mathematical problem-posing abilities and their mathematical content knowledge. Educational Studies in Mathematics, 83(1), 117-132. Doi:10.1007/s10649-012-9456-0

Voss, R. N. (2015) Teaching mathematics for social justice within a victorian public school for year nine mixed ability classes. Unpublished master's thesis, Curtin University, Pert, Australia.

Wade, R. C. (2007). Social justice for social justice - teaching strategies for the elementary classroom. (1st ed.). New York: Teachers College Press.

Yıldırım, A. \& Şimşek, H. (2008). Sosyal bilimlerde nitel araştırma yöntemleri. Ankara: Seçkin.

Yıldız, Z. (2014). Matematikte problem kurma çalışmalarının öğretmen adaylarının problem kurma becerilerine ve üstbilişsel farkındalık düzeylerine etkisi. Unpublished doctoral dissertation, Marmara University, İstanbul, Turkey.

Yıldız, Z. \& Özdemir, A. Ş. (2014). A study on the problem posing performance of student mathematics teachers. International Journal of Academic Research, 6(5), 44-48. 